\title{
Analytical method validation to evaluate dithiocarbamates degradation in biobeds in South of Brazil
}

\author{
Catiucia S. Vareli ${ }^{\mathrm{a}}$, Ionara R. Pizzutti ${ }^{\mathrm{a}, *}$, Luciano Gebler ${ }^{\mathrm{b}}$, Carmem D. Cardoso ${ }^{\mathrm{a}}$, Daniela S.H. Gai ${ }^{\mathrm{a}}$, \\ Marlos E.Z. Fontana ${ }^{\mathrm{a}}$ \\ ${ }^{a}$ UFSM - Federal University of Santa Maria, Chemistry Department, Center of Research and Analysis of Residues and Contaminants (CEPARC), Campus, 97105-900 \\ Santa Maria, RS, Brazil

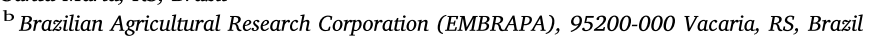

\section{A R T I C L E I N F O}

\section{Keywords:}

Biobed

Biomixture

Dithiocarbamates

Degradation

GC-MS

\begin{abstract}
A B S T R A C T
In order to evaluate the efficiency of biobeds on DTC degradation, the aim of this study was to apply, optimize and validate a method to determine dithiocarbamate (mancozeb) in biobeds using gas chromatography-tandem mass spectrometry (GC-MS).

The DTC pesticide mancozeb was hydrolysed in a tin (II) chloride solution at $1.5 \%$ in $\mathrm{HCl}\left(4 \mathrm{~mol} \mathrm{~L}^{-1}\right)$, during $1 \mathrm{~h}$ in a water bath at $80^{\circ} \mathrm{C}$, and the $\mathrm{CS}_{2}$ formed was extracted in isooctane. After cooling, $1 \mathrm{~mL}$ of the organic layer was transferred to an auto sampler vial and analyzed by GC-MS

A complete validation study was performed and the following parameters were assessed: linearity of the analytical curve $\left(\mathrm{r}^{2}\right)$, estimated method and instrument limits of detection and limits of quantification (LODm, LODi, LOQm and LOQi, respectively), accuracy (recovery\%), precision (RSD\%) and matrix effects. Recovery experiments were carried out with a standard spiking solution of the DTC pesticide thiram. Blank biobed (biomixture) samples were spiked at the three levels corresponding to the $\mathrm{CS}_{2}$ concentrations of 1,3 and $5 \mathrm{mg} \mathrm{kg}^{-1}$, with seven replicates each $(\mathrm{n}=7)$.

The method presented satisfactory accuracy, with recoveries within the range of $89-96 \%$ and RSD $\leq 11 \%$. The analytical curves were linear in the concentration range of $0.05-10 \mu \mathrm{g} \mathrm{CS}_{2} \mathrm{~mL}^{-1}\left(\mathrm{r}^{2}>0.9946\right)$. LODm and LOQm were 0.1 and $0.5 \mathrm{mg} \mathrm{CS} \mathrm{kg}^{-1}$, respectively, and the calculated matrix effects were not significant ( $\leq 20 \%$ ). The validated method was applied to 80 samples (biomixture), from sixteen different biobeds (collected at five sampling times) during fourteen months. Ten percent of samples presented $\mathrm{CS}_{2}$ concentration below the LOD $\left(0.1 \mathrm{mg} \mathrm{CS}_{2} \mathrm{~kg}^{-1}\right)$ and $49 \%$ of them showed results below the LOQ $\left(0.5 \mathrm{mg} \mathrm{CS}_{2} \mathrm{~kg}^{-1}\right)$, which demonstrates the biobeds capability to degrade DTC.
\end{abstract}

\section{Introduction}

Pesticides have a great importance to agriculture worldwide. However, their current releases and discharges into environment lead to a general concern and awareness about their effects and consequences [1]. Inadequate management of pesticides can result in contamination of surface water, groundwater and soil. Contamination of water bodies can occur via point sources that are mainly associated with localized situation, e.g. filling of sprayer tanks and washing equipments after use. Spraying equipment is normally filled at a particular place on the farm, often in the farmyard near a water source [2-5].

To prevent pollution during filling and cleaning of agricultural spraying equipment and accidental spillages in farms [5], biological decomposition of pesticides has being considered the most important and effective way to remove these compounds from the environment. Its efficiency is attributed to microorganisms which have the ability to interact both chemically and physically with pesticides promoting structural changes or complete degradation of target molecules [6]. This has been an environmentally and economically viable alternative, reducing costs and/or eliminating industrial processes [7-9].

A system that retains and degrades pesticides, known as biobed, was firstly developed in Sweden during the 1990s [1,3,10]. Such systems were later implemented in many countries of Europe [10] and are currently spreading through Latin America [11] and Asia [5]. Biobeds can be easily constructed using relatively inexpensive materials. They have as main function to retain and degrade pesticides from possible spills, preventing them to reach soil, groundwater and surface water

\footnotetext{
* Corresponding author.

E-mail address: ionara.pizzutti@ceparc.com.br (I.R. Pizzutti).
} 


\section{$[6,9,12-14]$.}

A classical biobed system consists of three layers including clay, biomixture and grass. Clay is used as an impermeable layer and decreases the water flow downward and to increase the pesticides retention. The grass layer regulates the system, retains the pesticides and controls the leaching of those with high mobility increasing the biobed efficiency [10]. The biomixture consists normally of straw, peat and soil (ratio $2: 1: 1 ; \mathrm{w} / \mathrm{w} / \mathrm{w}$ ). Each component of the biomixture and their interactions with water are important to an efficient and durable capacity of pesticides degradation [10].

The straw enhances microbial activity stimulating the growth of white rot fungi (Phanerochaete chrysosporium) which degrades lignin through the production of ligninolytic enzymes. These ones produce phenoloxidase enzymes that have a high specificity and are thereby able to degrade a wide range of pesticides residues [3,11]. Microbiological activity is essential to biobeds [15] and also affects the oxygen availability $[16,17]$.

Soil provides sorption and has to contain an appropriate amount of humus and clay to promote microbial activity [10]. Peat contributes to the sorption capacity, moisture control and abiotic pesticide degradation. It also decreases the $\mathrm{pH}$ of biomixture favoring microbial activity [18].

In agriculture, dithiocarbamates (DTC) have been used for over 50 years and they are among the most used fungicides all over the world [19-20]. DTC have broad spectrum of biological activity, low production costs and safe mammalian and environmental toxicity profile [21-23]. Among the DTC, mancozeb is the most used one to protect fruits, vegetables and ornamental plants from fungal diseases [21].

DTC pesticides are not suitable to multi-residue extraction together with other pesticides groups, due to their poor stability and insolubility in common extraction organic solvents. The main analytical method applied to determine DTC residues is an indirect method measuring the amount of carbon disulfide $\left(\mathrm{CS}_{2}\right)$ formed during acidic hydrolysis, which is derived from any DTC present in the samples [24].

The original method to determine DTC residues in food was developed by Keppel [25]. In this method $\mathrm{CS}_{2}$ is absorbed in an amine solution to form a complex which is then spectrophotometrically measured. A modification of Keppel method is based on sample acidic digestion with subsequent $\mathrm{CS}_{2}$ spectrophotometric determination [26]. Alternatively, the $\mathrm{CS}_{2}$ can be determined by gas chromatography (GC) either directly by headspace analysis [27] or dissolution of $\mathrm{CS}_{2}$ in an organic solvent (as isooctane) with subsequent GC analysis [24]. Therefore, the quantification of $\mathrm{CS}_{2}$ is still the routine method used for DTC determination and maximum residue limits (MRL) are specified for food in $\mathrm{mg}$ of $\mathrm{CS}_{2}$ per $\mathrm{kg}$ of matrix [22,27].

Several authors reported determination of DTC using GC with specific detectors like pulsed flame photometric detector (PFPD) [28], electron capture detector (ECD), nitrogen phosphorus detector (NPD) [29], ion trap detector (ITD-MS) [24] and triple quadrupole mass spectrometer (TQ-MS) $[21,23,29]$.

Most of studies published about biobeds evaluate pesticide degradation, in laboratory scale, according to the composition and temperature based on microbiological activity (respiration and phenoxylase content) $[5,18]$. There are just few studies related to biobed pesticide degradation on real field experiments [1,9].

To the best of our knowledge, until now, there is no method described in the literature for DTC determination in biobeds. Thus, the goal of the present study was to optimize and validate a previous existing sample preparation method followed by GC-MS analysis [24] specifically for biobeds, and later apply it to the $\mathrm{CS}_{2}$ determination in biobed samples from south of Brazil.

\section{Materials and methods}

\subsection{Chemicals and reagents}

Ultrapure water was obtained from a Mili-Q Gradient Water System from Millipore (Barueri, Brazil). Isooctane, pesticide grade was purchased from Lab-Scan Analytical Sciences (Dublin, Ireland). Toluene, pesticide grade, was purchased from Mallinckrodt (St. Louis, USA). Hydrochloric acid, analytical grade and tin (II) chloride analytical grade were obtained from Synth (São Paulo, Brazil). Thiram pesticide reference standard $(99.95 \%$ purity) was purchased from Dr. Ehrenstorfer (Augsburg, Germany) and carbon disulfide standard (99.9\%) was obtained from Sigma Aldrich (St. Louis, USA).

\subsection{Analytical solutions}

The standard stock solution of thiram was prepared in toluene at $1000 \mathrm{mg} \mathrm{L}^{-1}$. This solution was used as spiking solution for the recovery experiments. A $\mathrm{CS}_{2}$ standard stock solution was prepared in isooctane at $4000 \mathrm{mg} \mathrm{L}^{-1}$ and then diluted to yield a working solution of $40 \mathrm{mg} \mathrm{L}^{-1}$. Analytical standard solutions of $\mathrm{CS}_{2}$, at seven different concentration $\left(0.05,0.1,0.5,1,3,5\right.$ and $\left.10 \mathrm{mg} \mathrm{CS}_{2} \mathrm{~L}^{-1}\right)$, were prepared by a dilution of the working solution $\left(40 \mathrm{mg} \mathrm{L}^{-1}\right)$ in organic solvent (isooctane/toluene $(9: 1, \mathrm{v} / \mathrm{v})$ and in blank biomixture extract (matrix-matched standards). All these solutions were stored in freezer at $-18{ }^{\circ} \mathrm{C}$. The tin (II) chloride $1.5 \%(\mathrm{~m} / \mathrm{v})$ solution was prepared by the direct dissolution of $15 \mathrm{~g}$ of tin (II) chloride in hydrochloric acid $\left(4 \mathrm{~mol} \mathrm{~L}^{-1}\right)$.

\subsection{Chromatographic conditions}

GC-MS experiments were performed on a Varian gas chromatograph 450-GC (Middelburg, The Netherlands) integrated to a Bruker 320-MS triple quadrupole mass spectrometer (Walnut Creek, CA, USA). The data acquisition and processing was done with the MS Workstation 6.9.3 (Varian, USA). The GC-MS/MS was equipped with a CP-3800 autosampler (Middelburg, The Netherlands) and a 1079 programmed temperature vaporizing (PTV) injector provided with a glass liner (3.4 $\mathrm{mm}$ i.d., $54 \mathrm{~mm}$ length) which was packed with carbofrit.

The chromatographic separation was performed on a capillary column, CP-Sil $8 \mathrm{CB}(50 \mathrm{~m} \times 0.32 \mathrm{~mm}$ i.d. $\times 1.2 \mu \mathrm{m}$ film thickness $)$. The oven temperature program started at $45^{\circ} \mathrm{C}$ (held for $4 \mathrm{~min}$ ), and increasing $30^{\circ} \mathrm{Cmin}^{-1}$ up to $230^{\circ} \mathrm{C}$. The total analysis time was 12.2 min. Helium was used as carrier gas at a flow-rate of $1 \mathrm{~mL} \mathrm{~min}^{-1}$. Injections were done in the split mode (ratio 1:5) and the injector temperature was $250^{\circ} \mathrm{C}$. The TQ-MS was operated in the positive electron impact (EI) ionization mode. Data acquisition was performed in the selected-ion monitoring (SIM) mode, with the automatic search parameter set for the ion $76(\mathrm{~m} / \mathrm{z})$. The temperatures of the transfer line, the ion source and the manifold were set at 285,290 and $40^{\circ} \mathrm{C}$, respectively.

It is known that the $\mathrm{CS}_{2}$ molecular weight is 76 and due to lowmolecular mass the corresponding (product ion) mass spectra are not rich in peaks of fragments ions. However, other criteria have to be taken into account for some particular cases, as for $\mathrm{CS}_{2}$, because the generally preferred ions with higher masses are not available. Confirmation can be performed with the isotope peak of $m / z 78$ and the very specific isotopic ratio of $10: 1 .(m / z 76 / 78)$. Full identification is additionally based on the criteria, such as the correct retention time ( $\pm 0.1 \mathrm{~min}$, for sample relative to standard) and the same chromatographic peak shapes and alignment of peaks in the reconstructed ion chromatograms of both $m / z 76$ and 78 .

\subsection{Method validation}

Considering the fact there is no document established for method validation criteria specifically for biobeds, The SANTE Guidance document SANTE/Nr.11945/2015 [33] was taken as basis, although this guide is applied for assessment of pesticides in food and feed. The validation of the analytical method assessing the following parameters: linearity of the analytical curves $\left(\mathrm{r}^{2}\right)$, limit of detection (LOD) and limit 
of quantification (LOQ), accuracy (recovery \%), precision (RSD \%), dynamic linear range and matrix effects $(\%)$.

To evaluate the linearity of the analytical curves, analytical standard solutions of 7 concentrations $(0.05,0.1,0.5,1,3,5$ and $10 \mathrm{mg} \mathrm{CS}$ $\mathrm{L}^{-1}$ ) were prepared in organic solvent and in blank biomixture extract. All analytical standard solutions were injected seven times, under repeatability conditions, resulting in sample sequence of 112 injections, including the blank solvent and blank matrix extract. The LODi was considered to be equal to the concentration at which signal to noise ratio $(\mathrm{S} / \mathrm{N})$ was $\geq 3$, whereas LOQi was considered to be equal to the concentration for which the $\mathrm{S} / \mathrm{N}$ is $\geq 10$.

For the recovery experiments blank biomixture was spiked with a thiram standard solution ( $1000 \mathrm{mg} \mathrm{L}^{-1}$ ) corresponding to the concentration of 1,3 and $5 \mathrm{mg} \mathrm{CS} \mathrm{kg}^{-1}$, with seven replicates for each spike level $(n=7)$ and extracted as described in 2.6. Accuracy and precision were determined as recovery and relative standard deviation percentages, respectively.

Recovery experiments were performed on two different days and by two different analysts for intermediate precision determination. Average recoveries of the seven replicates (for each spike level) were calculated individually from each analyst.

Matrix effects were calculated based on the slopes of analytical curves obtained from the analysis of the analytical standard solutions prepared in organic solvent and in blank biomixture extract as described by Dias et al. [30].

\subsection{Biobed system}

To evaluate mancozeb degradation, 9 biobeds systems were constructed in duplicate, named A and B, resulting in a total of 18 biobeds. Five of them contained biomixture (biobeds 1-5) and four contained two representative types of Brazilian Oxisol - "Latossolo" and "Nitossolo" (biobeds 6-9).

The biobeds which contained biomixture (biobeds 1-5) were constructed according to the Swedish model with a biomixture of straw, soil and peat at 50:25:25 (v/v) [12]". The soil that was used for biomixture preparation was a type of Latosolo characterized as "Bruno Alico", with clay, sand and silt content in the range of $65 \%, 8 \%$ and $27 \%$ respectively and it was collected $10 \mathrm{~cm}$ deep at the Embrapa station orchards.

The biobeds 6 and 7 were constructed only with Latossolo while the biobeds 8 and 9 were constructed only with Nitossolo. These soils (Latossolo and Nitossolo) were agricultural soils localized in a commercial orchard where the fruiting has been practiced for more than 10 years. They were collected from the superficial layer between zero and ten centimeters deep in order to maximize microbial life would provide "seed" for the bioremediation processes of the system.

The biobeds models were built using water tanks with a capacity of 3601 . The bottom was filled with crushed stone and a drainage tube was inserted leading to collect the leached. A thin layer of tulle fabric was added above the crushed stone layer. The tulle layer was covered by biomixture, latossolo or Nitossolo depending on specific biobed. Finally, the biobed was covered by a grass layer.

The biobeds $1 \mathrm{~A}$ and $1 \mathrm{~B}$ were not contaminated (blank biobed). Biobeds 2A, 2B, 3A and 3B were contaminated with a single dose of

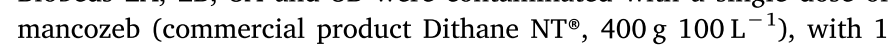
and $0.5 \mathrm{~L}$, respectively, to simulate an accidental spillage. Biobeds 4-9 (with A and B each) received a total of three effluent discards from a tank with residues of sprayers and effluents from the machines and equipments washing used in field application of the commercial pesticide Dithane $\mathrm{NT}^{\circledR}$ (Table 1). A double volume of effluent was added to the biobeds $4 \mathrm{~A}, 5 \mathrm{~A}, 6 \mathrm{~A}, 7 \mathrm{~A}, 8 \mathrm{~A}$, and $9 \mathrm{~A}$ in order to evaluate the biobed saturation capacity.

Sampling was done according to Table 2. Sub-samples were taken from the biobeds in the form of columns with plastic bags, aiming to reach all depths by collecting and at the same time, it was performed in at least 3 or more points (center and sides) all sub-samples being mixed, in order to make the composite sample representative. The plastic bags with the samples were stored in a freezer at $-80^{\circ} \mathrm{C}$ until analysis in order to avoid mancozeb degradation after the sampling step [31].

Humidity control in the biobeds systems was accomplished through the application of a plastic cover to prevent rainfall that can cause a system oversaturation and also by the addition of controlled volume of effluents from the machinery washes so, as to avoid leaching and effluents preventing recirculation in these biobeds.

\subsection{Sample preparation}

An amount of $50 \pm 0.5 \mathrm{~g}$ of blank biomixture was weighed into a $250 \mathrm{~mL}$ PTFE-coated, screw-capped glass bottle. For the recovery study volumes of $80 \mu \mathrm{L}, 240 \mu \mathrm{L}$ and $400 \mu \mathrm{L}$ of the thiram spike solution $\left(1000 \mathrm{mg} \mathrm{L}^{-1}\right)$ were added to blank biomixture corresponding to the spike concentrations of 1,3 and $5 \mathrm{mg} \mathrm{CS}_{2} \mathrm{~kg}^{-1}$, respectively.

After spiking, $25 \mathrm{~mL}$ of isooctane and $150 \mathrm{~mL}$ of tin (II) chloride solution, $1.5 \%$ in $\mathrm{HCl}\left(4 \mathrm{~mol} \mathrm{~L}^{-1}\right)$ were added. The bottles were closed and placed into an automatic water bath shaker at $80^{\circ} \mathrm{C}$ for $1 \mathrm{~h}$. The bottles were then cooled to room temperature and an aliquot of $1 \mathrm{~mL}$ of the upper layer was transferred to auto sampler vials and analyzed by GC-MS. The DTC concentration was determined as $\mathrm{CS}_{2}$.

\section{Results and discussion}

Studies involving biobeds used for pesticide residue management are recent in Brazil. The first results indicate that some structural changes have to be done in biobeds in order to meet the European standard efficiency. Experiments developed at the Brazilian Agricultural Research Corporation (EMBRAPA) demonstrated that the biobeds are more efficient in warm climates such as tropical and subtropical, because high temperatures favor microorganisms growth [31].

The main methods for DTCs determination are based on their degradation into $\mathrm{CS}_{2}$ which is derived from any DTC present in the sample. Maximum Residue limits for all DTCs in the Pesticides Regulations are therefore also set as "expressed as $\mathrm{CS}_{2}$ ". If the $\mathrm{CS}_{2}$ origin is known, an appropriate conversion factor can be used to give a result expressed as the corresponding DTC from the $\mathrm{CS}_{2}$ result. In this study, thiram was used for the validation studies. In this case, $1 \mathrm{~mol}$ of decomposed thiram produces $2 \mathrm{~mol}$ of $\mathrm{CS}_{2}$. The molecular weight of thiram is $240 \mathrm{~g}$ and $\mathrm{CS}_{2}$ is $76 \mathrm{~g}(2 \mathrm{~mol}=152 \mathrm{~g}$ ). The conversion factor is thus $240 / 152=1.58$, and the concentration of thiram $=\mathrm{CS}_{2}$ concentration $\times 1.58[24]$.

\subsection{Method validation}

\subsubsection{Linearity, $L O D$ and $L O Q$}

Analytical curves were constructed based on the detector response (chromatographic peak areas) of the analytical standard solutions prepared in organic solvent and in blank biomixture extract. Both analytical curves presented satisfactory linearity $\left(r^{2}>0.99\right)$ within the concentration range of $0.05-10 \mathrm{mg} \mathrm{CS} \mathrm{L}^{-1}$. That is in accordance with DOQ-CGCRE 008 requirements [32] for validation criteria. Furthermore, to ensure the satisfactory linearity within the evaluated concentration range, the individual residuals deviation were calculated for each concentration of the analytical standard solutions prepared in blank biomixture extract plotted against the areas of chromatographic peaks. As shown in Fig. 1 the calculated residuals presented values from $-13 \%$ to $11 \%$, which is satisfactory considering the limits of $\pm 20 \%$ recommended by the SANTE Guidance Document [33].

The LODm and LOQm were determined based on the detector response for the analytical standard solutions of the analytical curves. Thus the LOD was set as $0.1 \mathrm{mg} \mathrm{CS}_{2} \mathrm{~L}^{-1}$ and LOQ $0.5 \mathrm{mg} \mathrm{CS}_{2} \mathrm{~kg}^{-1}$. The LOD and LOQ values are suitable, considering the complexity of the biobed matrix and the method simplicity, since pre-concentration and/ 
Table 1

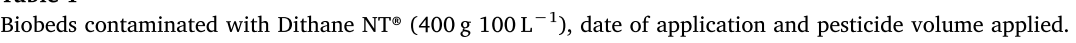

\begin{tabular}{|c|c|c|c|c|c|c|c|c|c|c|c|c|}
\hline \multirow[t]{4}{*}{ Application date } & \multicolumn{12}{|c|}{ Biobeds types/Dithane $\mathrm{NT}^{\circledast}$ volume (L) applied } \\
\hline & \multirow{2}{*}{\multicolumn{2}{|c|}{$\begin{array}{l}4 \\
\text { Biomixture }\end{array}$}} & \multirow{2}{*}{\multicolumn{2}{|c|}{$\begin{array}{l}5 \\
\text { Biomixture }\end{array}$}} & \multirow{2}{*}{\multicolumn{2}{|c|}{$\begin{array}{l}6 \\
\text { Latossolo }\end{array}$}} & \multirow{2}{*}{\multicolumn{2}{|c|}{$\begin{array}{l}7 \\
\text { Latossolo }\end{array}$}} & \multirow{2}{*}{\multicolumn{2}{|c|}{$\begin{array}{l}8 \\
\text { Nitossolo }\end{array}$}} & \multirow{2}{*}{\multicolumn{2}{|c|}{$\begin{array}{l}9 \\
\text { Nitossolo }\end{array}$}} \\
\hline & & & & & & & & & & & & \\
\hline & A & $\mathrm{B}$ & A & B & A & B & A & $\mathrm{B}$ & A & $\mathrm{B}$ & A & B \\
\hline $18 / 12 / 13$ & 50 & 50 & 25 & 25 & 50 & 50 & 25 & 25 & 50 & 50 & 25 & 25 \\
\hline $06 / 03 / 14$ & 50 & 50 & 25 & 25 & 50 & 50 & 25 & 25 & 50 & 50 & 25 & 25 \\
\hline $14 / 03 / 14$ & 50 & 50 & 25 & 25 & 50 & 50 & 25 & 25 & 50 & 50 & 25 & 25 \\
\hline Total (L) & 150 & 150 & 75 & 75 & 150 & 150 & 75 & 75 & 150 & 150 & 75 & 75 \\
\hline
\end{tabular}

Table 2

Sampling schedule after biobed contamination with Dithane $\mathrm{NT}^{\circledast}$ (mancozeb).

\begin{tabular}{lll}
\hline Biobed sampling time & Date & Time after contamination (months) \\
\hline T0 & December 2013 & 0 \\
T1 & February 2014 & 2 \\
T2 & April 2014 & 4 \\
T3 & July 2014 & 7 \\
T4 & August 2014 & 8 \\
T5 & February 2015 & 14 \\
\hline
\end{tabular}

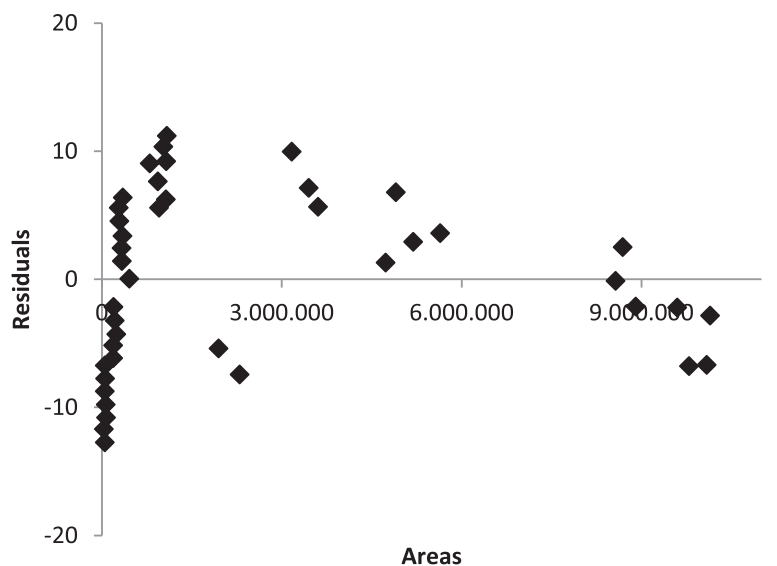

Fig. 1. Residuals of the analytical curve obtained from analytical standard solutions prepared in blank biomixture extract.

or clean-up steps are not required.

\subsubsection{Matrix effects}

The matrix effects are observed as an increase or decrease in the detector response for a specific analyte present in the matrix extract compared to the detector response for the same analyte in organic solvent [30]. In this study the matrix effects were calculated based on the slopes of the analytical curves obtained from analytical standard solutions prepared in organic solvent and in blank biomixture extract (Fig. 2). According to SANTE Guidance Document [33] matrix effects within $\pm 20 \%$ are considered acceptable for pesticide residue analysis. Thus, the use of matrix-matched calibration standards is not really necessary for adequate quantification of $\mathrm{CS}_{2}$ via the method applied in this study, because the matrix effect obtained was $17 \%$.

\subsubsection{Recovery studies}

Blank biomixture portions were spiked with a thiram standard solution at the levels of 1, 3 and $5 \mathrm{mg} \mathrm{CS} \mathrm{kg}^{-1}$. As can be seen in Table 3, in the first validation study, satisfactory results were obtained with recoveries in the range of $88-96 \%$ and $\mathrm{RSD}$ from $9 \%$ to $10 \%$. The average recoveries and RSD are shown in Table 3.

The method intermediate precision was evaluated performing a second validation study at the same conditions. As shown in Table 4,

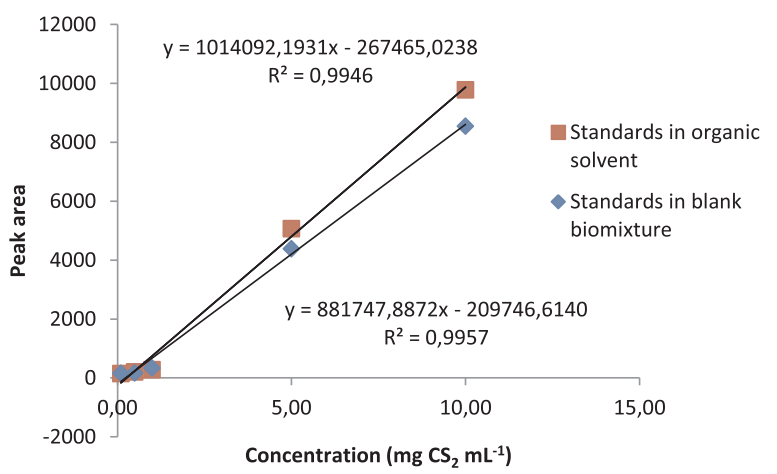

Fig. 2. Comparison between $\mathrm{CS}_{2}$ analytical curves obtained from analytical solutions prepared in isooctane/toluene (9:1) and also in blank biomixture extract.

Table 3

Average recoveries (\%) and RSD (\%) values for blank biomixture spiked with thiram, at three concentration levels.

\begin{tabular}{lll}
\hline $\begin{array}{l}\text { Spike concentrations ( } \mathrm{mg} \mathrm{CS}{ }_{2} \\
\left.\mathrm{~kg}^{-1}\right)\end{array}$ & $\begin{array}{l}\text { Recovery average (\%) } \\
(\mathrm{n}=7)\end{array}$ & RSD average (\%) \\
\hline 1 & 88 & 9 \\
3 & 98 & 9 \\
5 & 96 & 10 \\
\hline
\end{tabular}

recoveries were within the range of $91-118 \%$ and RSD $\leq 15 \%$, being satisfactory to meet the analytical method validation criteria for accuracy and precision.

Intermediate precision (Table 5) experiment was evaluated varying two parameters, different analysts and different days. The RSD values for intermediate precision tests were within acceptable range (2-15\%). It demonstrated agreement between both validation experiments irrespective of analyst and day of analysis, under identical conditions.

\subsection{Biobed system and dithiocarbamate degradation}

The environmental mobility and persistence of any pesticide is primary controlled by the soil sorption characteristics, water solubility and half-life of the pesticide. Highly soluble pesticides with low sorption capacity tend to move more quickly through the biobed than pesticides with high sorption capacity. This fact reduces residence time

\section{Table 4}

Average recoveries (\%) and RSD (\%) values for blank biomixture spiked with thiram, at three concentration levels, for the intermediate precision study.

\begin{tabular}{lll}
\hline $\begin{array}{l}\text { Spike concentrations (mg of } \mathrm{CS}_{2} \\
\left.\mathrm{~kg}^{-1}\right)\end{array}$ & $\begin{array}{l}\text { Recovery average (\%) } \\
(\mathrm{n}=7)\end{array}$ & RSD average (\%) \\
\hline 1 & 91 & 15 \\
3 & 111 & 10 \\
5 & 118 & 12 \\
\hline
\end{tabular}


Table 5

RSD (Intermediate precision) calculated from the thiram recoveries (expressed as $\mathrm{CS}_{2}$ ) obtained on different days and by different analysts.

\begin{tabular}{llll}
\hline \multirow{2}{*}{ Spike concentration $\left(\mathrm{mg} \mathrm{CS}_{2} \mathrm{~kg}^{-1}\right)$} & \multicolumn{2}{l}{ Average recovery \% $(\mathrm{n}=7)$} & \multirow{2}{*}{ RSD (\%) } \\
\cline { 2 - 3 } & Analyst 1 & Analyst 2 & \\
\hline 1 & 86 & 91 & 2 \\
3 & 98 & 111 & 8 \\
5 & 96 & 118 & 15 \\
\hline
\end{tabular}

diminishing the opportunities for microorganisms to degrade those pesticides [3].

Most pesticides are degraded by co-metabolic process, by metabolizing constituents within the biobed (straw). Bacteria and fungi produce enzymes which are able to break down toxic chemicals that otherwise would not be able to degrade [18]. However, different pesticide structures have different susceptibility to the oxidative enzymes produced by bacteria and fungi. Therefore, even pesticides with high sorption capacity that are retained within the biobed may experience low degradations rates [3].

Little is known regarding to the composition as well as to the dynamics of microbial community in biobed systems. There are evidences that bacterial concentration are involved in relevant process on biobed systems such as decomposition of organic matter coming from plant debris and organic pollutants degradation [34-37]

Mancozeb has a rapid degradation via hydrolysis, photolysis and oxidation in aqueous medium and it has low persistence in soil with half-life between 2 and 8 days in aerobic and anaerobic soils, respectively [21]. Table 6 presents results of biobed sample analysis, in which an accidental spillage was simulated, using a single application of $1 \mathrm{~L}$ (biobed 2A and 2B) and $0.5 \mathrm{~L}$ (biobed $3 \mathrm{~A}$ and $3 \mathrm{~B}$ ) of Dithane $\mathrm{NT}^{\circledR}$

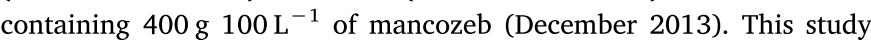
was done over a total period of fourteen months.

Regarding to the results of Table 6 , it is possible to observe that $40 \%$ of biobed samples presented $\mathrm{CS}_{2}$ concentration below the LOD, while $45 \%$ of samples showed $\mathrm{CS}_{2}$ concentration below the LOQ and just $15 \%$ of them had $\mathrm{CS}_{2}$ concentrations above the LOQ $\left(0.6-0.8 \mathrm{mg} \mathrm{CS} \mathrm{kg}^{-1}\right)$. These results demonstrate the high depuration efficiency of the studied biobeds. The higher depuration of mancozeb could be attributed to their rapid degradation, since DTC are known by the high instability in environment, being generally unstable in the presence of moisture, oxygen and in biological systems [22]. Concentrations > LOQ were detected in the samples 2A, 2B and 3B after two months (T1) of contamination. At the second sampling time (T2), four months after contamination, it was not possible anymore to quantify the exact concentration of $\mathrm{CS}_{2}$ in the samples, which indicates that macozeb was almost completely degraded.

The Fig. 3 shows the GC (SIM) chromatograms of $\mathrm{CS}_{2}$ obtained by the biobed $2 \mathrm{~A}$ analysis, which received a single concentrated dose of mancozeb (400 $\left.100 \mathrm{~L}^{-1}\right)$, in two different sampling times (T1 and

Table 6

$\mathrm{CS}_{2}$ concentration in biomixtures, at five different sampling times, collected after the simulation of an accidental spillage of Dithane $\mathrm{NT}^{\mathrm{TM}}{ }^{\circ}$.

\begin{tabular}{|c|c|c|c|c|c|}
\hline \multirow[t]{2}{*}{ Biobeds } & \multicolumn{5}{|c|}{ Concentration average $(\mathrm{n}=3)\left(\mathrm{mg} \mathrm{CS} \mathrm{kg}^{-1}\right) / \mathrm{RSD} \%$} \\
\hline & $\begin{array}{l}\mathrm{T} 1 \text { (two } \\
\text { months) }\end{array}$ & $\begin{array}{l}\mathrm{T} 2 \text { (four } \\
\text { months) }\end{array}$ & $\begin{array}{l}\text { T3 (seven } \\
\text { months) }\end{array}$ & $\begin{array}{l}\text { T4 (eigth } \\
\text { months) }\end{array}$ & $\begin{array}{l}\text { T5 (fourteen } \\
\text { months) }\end{array}$ \\
\hline $2 \mathrm{~A}$ & $0.8 / 12$ & $<$ LOQm & $<\mathrm{LODm}$ & $<\mathrm{LODm}$ & $<$ LODm \\
\hline $2 B$ & $0.6 / 4$ & $<\mathrm{LOQm}$ & $<\mathrm{LOQm}$ & $<$ LODm & $<$ LODm \\
\hline $3 \mathrm{~A}$ & $0.7 / 3$ & $<\mathrm{LOQm}$ & $<\mathrm{LOQm}$ & $<$ LOQm & $<$ LOQm \\
\hline $3 \mathrm{~B}$ & $<\mathrm{LOQm}$ & $<\mathrm{LOQm}$ & $<\mathrm{LODm}$ & $<\mathrm{LODm}$ & $<\mathrm{LODm}$ \\
\hline
\end{tabular}

LOQm: Method quantification limit $\left(0.5 \mathrm{mg} \mathrm{CS} \mathrm{kg}^{-1}\right)$.

LODm: Method detection limit $\left(0.1 \mathrm{mg} \mathrm{CS} \mathrm{kg}^{-1}\right)$.
T5). Comparing both chromatograms it is possible to see the lower intensity of the $\mathrm{CS}_{2}$ signal in the chromatogram $\mathrm{B}$. These results provide evidence of biobed being highly successful in reducing DTC concentrations when receiving an accidental spillage of mancozeb. Moreover, the saturation capacity of the biobeds was evaluated when double volume of mancozeb was added to the biobeds $2 \mathrm{~A}$ and $2 \mathrm{~B}$. As shown in Table 6 , the biobed maintained its degradation capacity because the $\mathrm{CS}_{2}$ concentrations where < LOD after 14 month of contamination.

The $\mathrm{CS}_{2}$ concentrations determined for biobeds 4-9 are shown in Table 7. These biobeds were constructed with different compositions (biomixture, Latossolo and Nitossolo) and received machinery effluent of Dithane $\mathrm{NT}^{\circledast}$. Among all analyzed samples, just the biobed 4A presented a $\mathrm{CS}_{2}$ concentration higher than $10 \mathrm{mg} \mathrm{kg}^{-1}$ (at T1).

As can be seen in Table 7, for the sampling times T1 and T5, $\mathrm{CS}_{2}$ concentrations decreased, especially for reactors 4B, 9A and 9B, which indicates the degradation of mancozeb since T2. Moreover the $\mathrm{CS}_{2}$ detected at sampling time $\mathrm{T} 1$ (biobeds $5 \mathrm{~A}$ and $5 \mathrm{~B}$ ) and $\mathrm{T} 4$, into the biobeds $6 \mathrm{~A}, 7 \mathrm{~A}$ and 7B was probably caused by dry beds because of non-homogeneous mixture of the soils. So, clods of soil (or peat) could be present in the biomixture, inducing sample collection with clods of low mancozeb concentration, while at other sampling times, samples may have contained high concentrations of mancozeb. Besides the failure of the incomplete sample homogenization, peat or soil could produce clods that retained the pesticide in various extents, influencing both the sampling and pesticide degradation processes.

The evaluation of the biobeds with biomixture (4 and 5) and biobeds with soil (6-9), showed some difference on mancozeb degradation, even in the biobed with biomixture, which had action of more quantity of fungi and bacteria. This fact also can be attributed to mancozeb properties, which has rapid degradation via hydrolysis, photolysis and oxidation to produce metabolites.

Soil characteristics such as $\mathrm{pH}$, oxy-reduction potential, concentration of organic and inorganic binders to which a metal, for example, can bind or adsorb, and also the presence of $\mathrm{Ca}^{2+}, \mathrm{Fe}^{2+}$ and $\mathrm{Mg}^{2+}$ may interfere on chemical and biological mancozeb availability, since their presence in the soil provides competition among them for the adsorption sites [38].

Latossolo and Nitossolo have almost the same $\mathrm{pH}$ value, organic matter and total organic carbon content, and these characteristics might not cause differences on the mancozeb availability. The main difference between those 2 types of soil is their metal quantity. Latossolo has a higher content of metallic ions $\left(7\right.$ and 2 cmolc $\mathrm{dm}^{-3}$ of $\mathrm{Ca}$ and $\mathrm{Mg}$, respectively, and $14,11,78$ and $271 \mathrm{mg} \mathrm{dm}^{-3}$ of $\mathrm{P}, \mathrm{Cu}, \mathrm{Fe}$, and $\mathrm{K}$ respectively) than Nitossolo (4 and $1 \mathrm{cmolc} \mathrm{dm}^{-3}$ of $\mathrm{Ca}$ and $\mathrm{Mg}$, respectively, and $2,18,55$ and $141 \mathrm{mg} \mathrm{dm}^{-3}$ of $\mathrm{P}, \mathrm{Cu}, \mathrm{Fe}$, and $\mathrm{K}$, respectively) [39].

Mancozeb is composed mainly by $\mathrm{Mn}$ and $\mathrm{Zn}$ [22] and has the ability to complex physiological metal ions such as $\mathrm{Cu}$. That is why mancozeb could have a greater availability in the presence of competing cations such as $\mathrm{Ca}^{2+}$ [38]. These mancozeb characteristics could explain the difference in data repeatability between two contaminated biobeds, observed by the mancozeb persistence in biobeds $6 \mathrm{~A}, 7 \mathrm{~A}$ and 7B.

The clay-rich surface layer would be expected to favor mancozeb decrease due sorption into soil, thus lowering mancozeb concentration in the pores containing water [3]. As the clay amount is different for Latossolo (30\%) and Nitossolo (47\%), clayey soils usually have a higher retention capacity, which also may interfere on degradation for $8 \mathrm{~A}$ and $8 \mathrm{~B}$ biobeds.

In Fig. 4 it is possible to see the smaller peaks obtained for $\mathrm{CS}_{2}$, in chromatograms B and C compared to chromatogram A, caused by a $\mathrm{CS}_{2}$ concentration reduction over three different sampling times.

Although the effects of pesticides can be studied isolated, on the field this reality is quite different, being necessary the integration of pesticides discharged into biobed, as long as it will receive residues of all types of insecticides, fungicides, herbicides, and all pesticides groups 


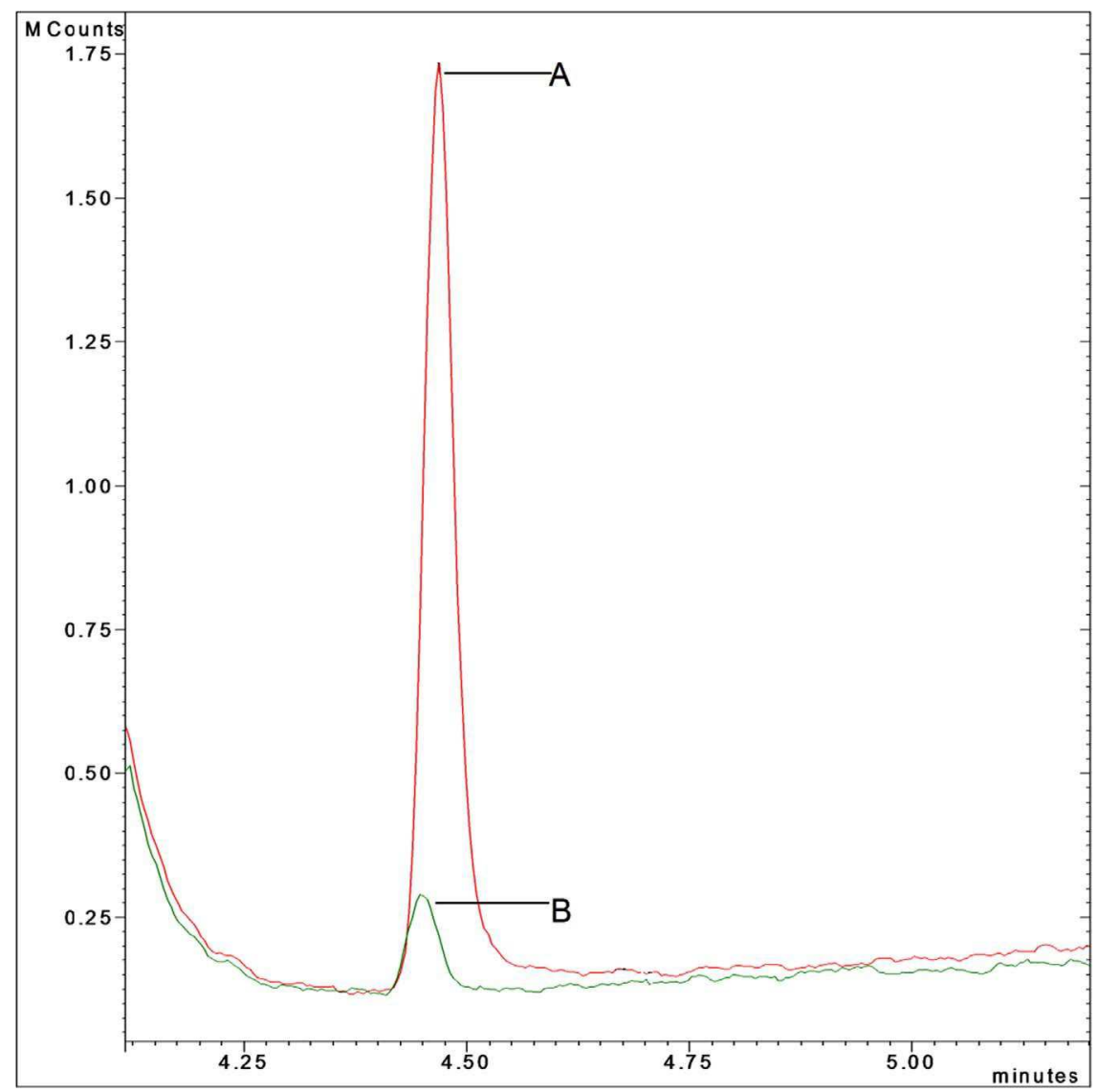

Fig. 3. SIM chromatograms of $\mathrm{CS}_{2}$ for biobed $2 \mathrm{~A}$, which received a single concentrated dose of mancozeb ( $400 \mathrm{~g} 100 \mathrm{~L}^{-1}$ ), simulating an accidental spillage, in two different sampling times (T1 and T5), obtained from biobeds samples collected at (A) two months and at ( B) fourteen months after contamination.

\section{Table 7}

$\mathrm{CS}_{2}$ concentration in biobed samples at five different sampling times, after receiving

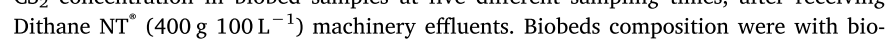
mixture -4 and 5; Latossolo -6 and 7; and Nitossolo -8 and 9 .

\begin{tabular}{|c|c|c|c|c|c|}
\hline \multirow[t]{2}{*}{ Biobeds } & \multicolumn{5}{|c|}{ Concentration (mg CS $\left.\mathrm{kg}^{-1}\right) / \mathrm{RSD}^{2} \%$} \\
\hline & $\begin{array}{l}\text { T1 (two } \\
\text { months) }\end{array}$ & $\begin{array}{l}\mathrm{T} 2 \text { (four } \\
\text { months) }\end{array}$ & $\begin{array}{l}\mathrm{T} 3 \text { (seven } \\
\text { months) }\end{array}$ & $\begin{array}{l}\text { T4 (eigth } \\
\text { months) }\end{array}$ & $\begin{array}{l}\text { T5 (fourteen } \\
\text { months) }\end{array}$ \\
\hline $4 \mathrm{~A}$ & $14 / 3$ & $3 / 30$ & $0.6 / 13$ & $<$ LOQm & $<$ LOQm \\
\hline $4 B$ & $8 / 7$ & $<\mathrm{LOQm}$ & $<$ LOQm & $<$ LOQm & $<$ LOQm \\
\hline $5 \mathrm{~A}$ & $9 / 6$ & $1 / 3$ & $<\mathrm{LOQm}$ & $<\mathrm{LOQm}$ & $<\mathrm{LOQm}$ \\
\hline $5 B$ & $0.9 / 32$ & $0.8 / 11$ & $<\mathrm{LOQm}$ & $<\mathrm{LOQm}$ & $<\mathrm{LOQm}$ \\
\hline $6 \mathrm{~A}$ & $6 / 29$ & $5 / 1$ & $3 / 40$ & $2 / 10$ & $<\mathrm{LOQm}$ \\
\hline $6 \mathrm{~B}$ & $6 / 32$ & $0.6 / 1$ & $<$ LOQm & $<$ LOQm & $<$ LOQm \\
\hline $7 \mathrm{~A}$ & $5 / 14$ & $2 / 9$ & $1 / 0.5$ & $1 / 1$ & $<$ LOQm \\
\hline $7 B$ & $3 / 4$ & $1 / 13$ & $0.6 / 8$ & $0.5 / 5$ & $<$ LOQm \\
\hline $8 \mathrm{~A}$ & $6 / 33$ & $1 / 21$ & $0.6 / 2$ & $<$ LOQm & $<$ LOQm \\
\hline $8 \mathrm{~B}$ & $3 / 4$ & $0.8 / 14$ & $0.5 / 0.1$ & $<\mathrm{LOQm}$ & $<\mathrm{LOQm}$ \\
\hline $9 \mathrm{~A}$ & $2 / 32$ & $<\mathrm{LOQm}$ & $<$ LOQm & $<\mathrm{LOQm}$ & $<\mathrm{LOQm}$ \\
\hline $9 \mathrm{~B}$ & $3 / 3$ & $<\mathrm{LOQm}$ & $<\mathrm{LOQm}$ & $<\mathrm{LOQm}$ & $<\mathrm{LOQm}$ \\
\hline
\end{tabular}

LOQm: Method quantification limit $\left(0.5 \mathrm{mg} \mathrm{CS}_{2} \mathrm{~kg}^{-1}\right)$.

that can be applied on the field. Microbial pesticides degradation in biobeds can be seen as the final result of a complex and interactive process between metabolic and co-metabolic functions. The relative importance of each process depends on the characteristics of each pesticide, but may be partially regulated by the composition of the biomixture [14].

The results of this study clearly demonstrate the effectiveness of a straw-peat-soil biobed in reducing mancozeb residues even when receiving substantial volumes of contaminated water from machinery washing. The contaminated water collected from the equipments and discharged into biobeds, allowed mancozeb degradation with biomixture or soil. It is essential to reduce pesticide concentrations to environmentally acceptable levels, in order to have a significant decrease of the water contamination risk.

\section{Conclusion}

A simple and efficient method for DTC determination in biobeds was optimized and validated. The dithiocarbamate pesticide mancozeb was hydrolysed to $\mathrm{CS}_{2}$ and then the $\mathrm{CS}_{2}$ was extracted from the complex biobed samples, using just one single hydrolysis/extraction step, followed by GC-MS analysis of $\mathrm{CS}_{2}$ in the extracts.

The developed analytical method was fully validated and accuracy was assessed by the analysis of spiked blank biomixture at 3 concentration levels. Recoveries of mancozeb (expressed as $\mathrm{CS}_{2}$ ) meet the validation criteria within the range of $89-98 \%$ and RSD $<11 \%$.

The analytical curve was linear $\left(\mathrm{r}^{2}>0.993\right)$ in the range of $0.05-10 \mathrm{mg} \mathrm{CS} \mathrm{L}^{-1}$. The extraction method is easy to apply and suitable to determine dithiocarbamates as $\mathrm{CS}_{2}$ in biobeds, due the fact that it does not requires any expensive equipment, just ones that are available in almost all laboratories. Thus, it is possible to analyse many samples simultaneously in a simplified way.

The analysis of biobed samples contaminated with mancozeb, in different times over a period of 14 month contaminated, showed a significant decrease of mancozeb concentration, proving that biobeds were effective on DTC degradation. Although these data are positive, when working with DTC, should be considered their rapid degradation in aqueous and acidic media. All DTC, as mancozeb, has the ability to release $\mathrm{CS}_{2}$ during degradation and/or biotransform in ethylene thiourea (ETU). However, at the same time, ETU needs a separate study from dithiocarbamate due to the need for a separate analytical method 


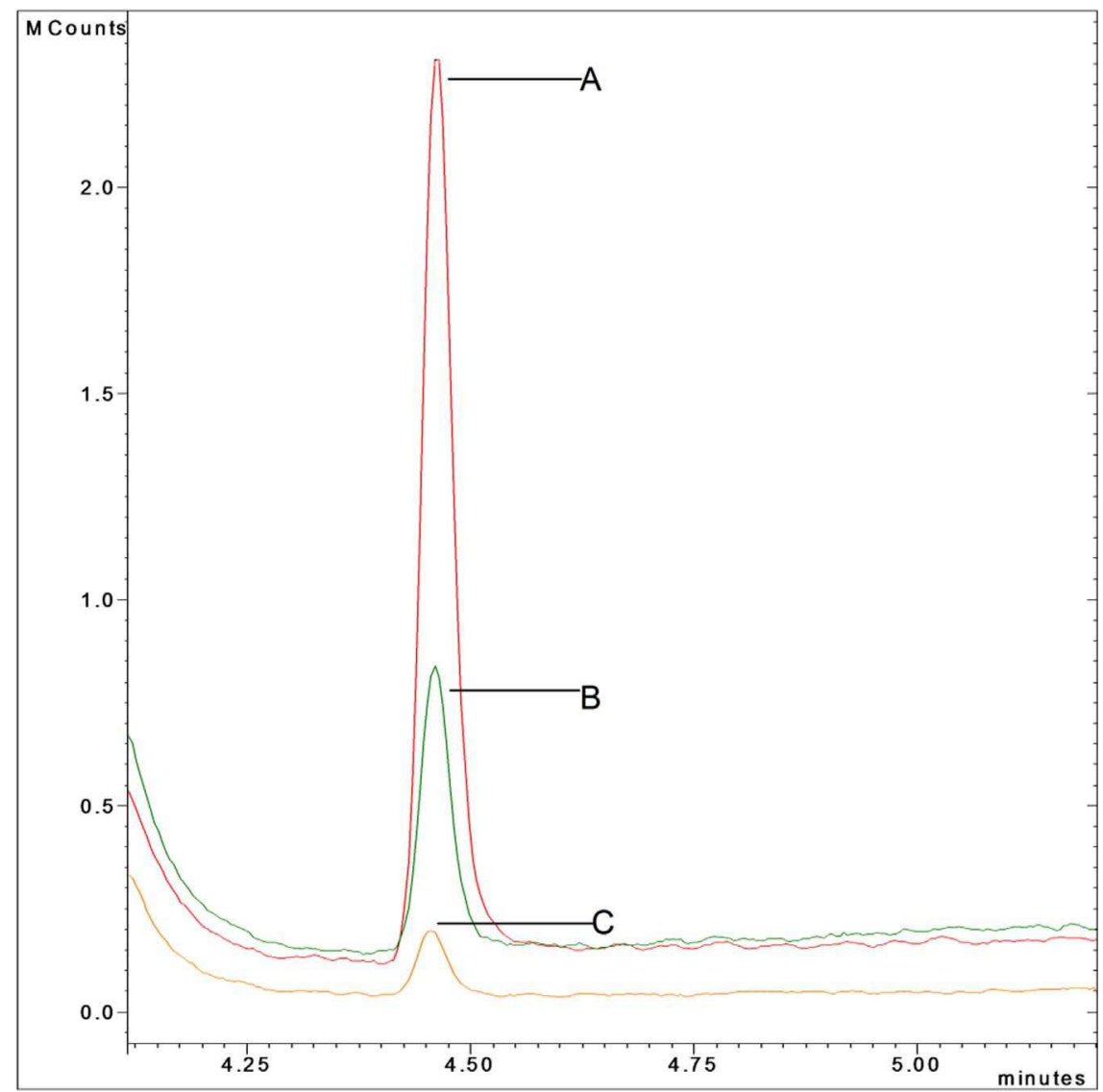

Fig. 4. SIM chromatograms of $\mathrm{CS}_{2}$ for biobed $6 \mathrm{~B}$ in three different sampling times, obtained from biobed samples collected at (A) two months, (B) six months and at (C) fourteen months after contamination with mancozeb effluents coming from washing machinery.

by GC-MS/MS or LC-MS/MS. ETU analysis in general is not very easy and especially the development of a new method for biobeds could be a very difficult job with unpredictable success. Thus, ETU analysis in biobeds will be an issue for the next study.

Considering that there is no MRL established in Brazil for pesticide residues in biobeds as well as no monitoring data available, this work is of utmost importance for a better understanding on biobeds efficacy for pesticide degradation in tropical and subtropical climates. Besides, biobed systems are environmentally friendly and very promising to reduce or avoid pesticide contamination elsewhere.

\section{Acknowledgement}

The authors gratefully acknowledge FINEP, MCTI, MAPA, CNPq for the financial support as well as the Brazilian Agricultural Research Corporation (EMBRAPA) from Vacaria, RS for the partnership on this study. We also thank the UFSM.

\section{References}

[1] L. Coppola, F. Comitini, C. Casucci, V. Milanovic, E. Monaci, M. Marinozzi, M. Taccari, M. Ciani, C. Vischetti, Fungicides degradation in an organic biomixture: impact on microbial diversity, New Biotechnol. 29 (2011) 99-106.

[2] L. Torstensson, Experiences of biobeds in practical use in Sweden, R. Soc. Chem (2000) 2016-2211.

[3] R.J. Cooper, P. Fitt, K.M. Hiscock, A.A. Lovett, L. Gumm, S.J. Dugdale, J. Rambohul, A. Williamson, L. Noble, J. Beamish, P. Hovesen, Assessing the effectiveness of a three-stage on-farm biobed in treating pesticide contaminated wastewater, J. Environ. Manag. 181 (2016) 874-882.

[4] M. Campos, C. Perruchon, P.A. Karas, D. Karavasilis, M.C. Diez, D.G. Karpouzas, Bioaugmentation and rhizosphere-assisted biodegradation as strategies for optimization of the dissipation capacity of biobeds, J. Environ. Manag. 187 (2017) 103-110.

[5] W. Gao, J. Liang, L. Pizzul, X.M. Feng, K. Zhang, M. del, P. Castillo, Evaluation of spent mushroom substrate as substitute of peat in Chinese biobeds, Int. Biodeterior. Biodegrad. 98 (2015) 107-112.

[6] M.C. Diez, Biological aspects involved in the degradation of organic pollutants, J. Soil Sci. Plant Nutr. 10 (2010) 244-267.

[7] P. Fogg, A.B.A. Boxall, Pesticide degradation in a biobed composting substrate, Pest Manag. Sci. 59 (2003) 527-537.

[8] L. Coppola, M.d.P. Casillo, C. Vischetti, Degradation of isoproturon and bentazone in peat- and compost based biomixtures, e, Pest Manag. Sci. 67 (2011) 107-113.

[9] N.H. Spliid, A. Helweg, K. Heinrichson, Leaching and degradation of 21 pesticides in a full-scale model biobed, Chemosphere 65 (2006) 2223-2232.

[10] M.d.P. Castillo, L. Torstensson, J. Stenstrom, Biobeds for environmental protection from pesticide use - a review, J. Agric. Food Chem. 56 (2008) 6206-6219.

[11] A. Rivero, S. Niell, M.P. Cerdeiras, H. Heinzen, Development of analytical methodologies to assess recalcitrant pesticide bioremediation in biobeds at laboratory scale, Talanta 153 (2016) 17-22.

[12] L. Torstensson, M.d.P. Castillo, Use of biobeds in Sweden to minimize environmental spill ages from agricultural spray equipment, Pestic. Outlook 8 (1997) 24-27.

[13] C. Vischetti, E. Monaci, A. Cardinali, P. Perucci, The effect of initial concentration, co-application and repeated applications on pesticide degradation in a Biobed mixture, Chemosphere 72 (2008) 1739-1743.

[14] E.C. Karanasios, N.G. Tsiropoulos, D.G. Karpouzas, Quantitative and qualitative differences in the metabolism of pesticides in Biobed substrates and soil, Chemosphere 93 (2013) 20-28.

[15] C. Vischetti, L. Coppola, E. Monaci, A. Cardinali, M.d.P. Castillo, Microbial impact of pesticide chlorpyrifos on Swedish and Italian biobeds, Agron. Sustain. Dev. 27 (2007) 267-272.

[16] G.R. Tortella, O. Rubilar, M. Cea, C. Wulff, O. Martínez, M.C. Diez, Biostimulation of agricultural biobeds with NPK fertilizer on chlorpyrifos degradation to avoid soil and water contamination, J. Soil Sci. Plant Nutr. 10 (4) (2010) 464-475.

[17] L. Coppola, M.d.P. Castillo, E. Monaci, C. Vischetti, Adaptation of the biobed composition for chlorpyrifos degradation to southern Europe conditions, J. Agric. Food Chem. 55 (2007) 396-401.

[18] M.d.P. Castillo, L. Torstensson, Effect of biobed composition, moisture, and temperature on the degradation of pesticides, J. Agric. Food Chem. 55 (2007) $5725-5733$.

[19] G. Crnogorac, W. Schwack, Determination of dithiocarbamate fungicide residues by liquid chromatography/mass spectrometry and stable isotope dilution assay, Rapid Commun. Mass Spectrom. 21 (2007) 4009-4016.

[20] L. Hoffman, L. Trombetta, D. Hardej, Ethylene bisdithiocarbamate pesticides Maneb 
and Mancozeb cause metal overload in human colon cells, Environ. Toxicol Pharmacol. 41 (2016) 78-83.

[21] S. Mujawar, S.C. Utture, E. Fonseca, J. Matarrita, K. Banerjee, Validation of a GCMS method for estimation of dithiocarbamate fungicide residues and safety evaluation of mancozeb in fruits and vegetables, Food Chem. 150 (2014) 175-181.

[22] G. Crnogorac, W. Schwack, Residue analysis of dithiocarbamate fungicides, Trends Anal. Chem. 28 (1) (2009) 40-50.

[23] B. Chefirat, M.E. Falsa, T. Abdessamed, H.R. Kallah, Development and validation of a GC-MS method for the determination of dithiocarbamate-fungicides residues in potatoes, Abstracts/Toxicol. Lett. 258 (2016) 172-173.

[24] I.R. Pizzutti, A.D. Kok, R.C. da Silva, G.N. Rohers, Comparison Between three chromatographic (GC-ECD, GC-PFPD and GC-ITD-MS) methods and a UV-vis spectrophotometric method for the determination of dithiocarbamates in lettuce, J. Braz. Chem. Soc. 28 (5) (2017) 775-781.

[25] G.E. Kepell, Collaborative study of the determination of dithiocarbamate residues by a modified carbon disulphide evolution method, J. AOAC Int. 54 (1971) 528-532.

[26] E.D. Caldas, M.C.C. Miranda, M.H. Conceição, L.C.K.R. de Souza, Dithiocarbamates residues in Brazilian food and the potential risk for consumers, Food Chem. Toxicol. 42 (2004) 1877-1883.

[27] R.B. Abakerli, R. Sparrapan, A.C.H.F. Sawya, M.N. Eberlin, J.L.P. Jara, N.R. Rodrigues, E.F. Fay, A.J.B. Luiz, T.D.L. Galvão, D. d.S. Martins, O.K. Yamanishi, H.H.B. Toledo, Carbon dissulfide formation in papaya under conditions of dithiocarbamate residue analysis, Food Chem. 188 (2015) (71-16).

[28] A.N.O. Jardim, D.C. Mello, F.C.S. Goes, E.F.F. Junior, E.D. Caldas, Pesticide residues in cashew apple, guava, kaki and peach: GC- $\mu \mathrm{ECD}, \mathrm{GC}-\mathrm{FPD}$ and LC-MS/MS multiresidue method validation, analysis and cumulative acute risk assessment, Food Chem. 164 (2014) 195-204.

[29] H. Berrada, M. Fernadez, M.J. Ruiz, J.C. Moltó, J. Mañes, G. Font, Surveillance of pesticide residues in fruits from Valencia during twenty months (2004/05), Food Control 21 (2010) 36-44.

[30] J.V. Dias, V. Cutillas, A. Lozano, A.R. Fernandez-Alba, I.R. Pizzutti, Determination of pesticides in edible oils by liquid chromatography-tandem mass spectrometry employing new generation materials for dispersive solid phase extraction clean-up, J. Chromatogr. A 1462 (2016) 8-18.

[31] L. Gebler, I.R. Pizzutti, C.D. Cardoso, O.K. Filho, D.J. Miquelluti, S.S. Regis, R.S. Santos, Bioreactors to organize the disposal of phytosanitary effluents of Brazilian apple production, Chem. Eng. Trans. 43 (2015) 343-348.

[32] DOQ-CGCRE-008. Orientação sobre validação de métodos analíticos. 〈http://www. inmetro.gov.br/Sidoq/Arquivos/Cgcre/DOQ/DOQ-Cgcre-8_04.pdf> (Accessed on 10 September 2017)

[33] SANTE, Guidance document on analytical quality control and validation procedures for pesticide residues analysis in food and feed, Document No. SANTE/11945/2015.

[34] G.R. Tortella, O. Rubilar, M. d.P. Castillo, M. Cea, R. Mella-Herrera, M.C. Diez, Chlorpyrifos degradation in a biomixture of biobed at different maturity stages, Chemosphere 88 (2012) 224-228.

[35] J.M.C. Diaz, L. Delgado-Moreno, R. Nuñez, R. Nogales, Enhancing pesticide degradation using indigenous microorganisms isolated under high pesticide load in bioremediation systems with vermicomposts, Bioresour. Technol. 214 (2016) 234-241.

[36] P.A. Karas, C. Perruchon, E. Karanasios, E.S. Papadopoulou, E. Manthou, S. Sitra, C. Ehaliotis, D.G. Karpouzas, Integrated biodepuration of pesticide-contaminated waste waters from the fruit-packaging industry using biobeds: bioaugmentation, risk assessment and optimized, J. Hazard. Mater. 320 (2016) 635-644.

[37] P. Karas, A. Metsoviti, V. Zisis, C. Ehaliotis, M. Omirou, E.S. Papadopoulou, U. Menkissoglou-Spiroudi, S. Manta, D. Komiotis, D.G. Karpouzas, Dissipation, metabolism and sorption of pesticides used in fruit-packaging plants: towards an optimized depuration of their pesticide-contaminated agro-industrial effluents, Sci. Total Environ. 530-531 (2015) 129-139.

[38] A.T. de Matos, M.P.F. Fontes, L.M. da Costa, M.A. Martinez, Mobility of heavy metals as related to soil chemical and mineralogical characteristics of Brazilian soils, Environ. Pollut. 111 (2001) 429-435.

[39] EMBRAPA, Sistema brasileiro de classificação dos solos, Embrapa, Brasília, 2013, p. 353. 